\title{
Synthesis and characterization of some metal complexes of 2- Phenyl-3,4-dihydro-quinazolin-4-yloxy)-acetic acid and their Biological Application
}

\author{
Mostafa.A.Hussien $^{1,2}$, W.Fathalla ${ }^{3}$, F. Mahmoud ${ }^{3}$ and M.I.Megahed ${ }^{3}$ \\ ${ }^{1}$ Department of Chemistry, Faculty of Science, Port Said University, Port Said, Egypt \\ ${ }^{2}$ Department of Chemistry, Faculty of Science, King Abdulaziz University, Jeddah, Kingdom of saudi arabia \\ ${ }^{3}$ Physics and Math. Engineering Dept., Faculty of Engineering, Port Said University, Port Said, Egypt
}

Abstract: 2-Phenyl-3,4-dihydro-quinazolin-4-yloxy)-acetic acid $\left(L_{l}\right)$ metal complexes with $\mathrm{Mn}^{2+}, \mathrm{Co}^{2+}, \mathrm{Ni}^{2+}$ $\mathrm{Cu}^{2+}$, and $\mathrm{Zn}^{2+}$ ions were studied and the structure of the complexes were elucidated using elemental analyses, infrared (IR), ${ }^{1} \mathrm{H}$ nuclear magnetic resonance (NMR), magnetic moment and thermal analysis measurements. Besides the characterization of complexes by physicochemical technique,

Biological activities of the synthesized complexes were examined against some microbial strains for evaluation of antibacterial and antifungal activities.

\section{Introduction}

Interest in coordination chemistry is increasing continuously with the preparation of organic ligands containing a variety of donor groups [1-3] and it is multiplied many fold when the ligands have biological importance $[4,5]$.

Quinazolinones are one of the most important core structures present in many natural products as well as synthetic drugs. 4-(3H)-quinazolinone is frequently encountered heterocyclic moeity in medicinal chemistry known for more than a century. Quinazolinone derivatives attract a widespread interest due to the diverse biological activities [6], associated with them. They are pharmaceutically important as antituberculars [7], antibacterial [8], antiparkinsons [9], antihelmintics [10], and they also show blood platelet antiaggregatingactivity.[11]

Furthermore and taking into consideration the use of metal complexes in the treatment of some diseases, mentioned above, we described the coordination behavior of (2-Phenyl-3,4-dihydro-quinazolin-4yloxy)-acetic acid $\left(\mathrm{L}_{1}\right)$ (Fig 1) towards some transition elements.<smiles>O=C(O)COC1NC(c2ccccc2)=Nc2ccccc21</smiles>

Fig.1. Structure of $\mathrm{L}_{1}$

\subsection{Materials}

\section{Experimental}

All the compounds, solvents and nitrate salts $\mathrm{Mn}^{2+}, \mathrm{Co}^{2+}, \mathrm{Ni}^{2+} \mathrm{Cu}^{2+}$, and $\mathrm{Zn}^{2+}$ used were purchased from Aldrich and Sigma and used as received without further purification.

\subsection{Instruments}

Elemental analysis was carried out by standard micro chemical methods using a Perkin-Elmer CHN 2400 and the metal contents were determined gravimetrically by ignition weighted samples in air atmosphere at $1,073 \mathrm{~K}$ to constant weight as the metal oxide forms. The Infra-Red absorption spectrum was obtained in the solid state in the form of $\mathrm{KBr}$ discs and recorded using FTIR Shimadzu spectrophotometer (4000$400 \mathrm{~cm}^{-1}$ ) model $8201 \mathrm{DC}$, at the department of Chemistry, Faculty of Science, Cairo University. TG-DTG measure-ments were carried out under $\mathrm{N}_{2}$ atmosphere within the temperature range from room temperature to $1,073 \mathrm{~K}$ using a Shimadzu TGA-50H thermal analyzer. Electronic spectra were obtained using a Jenway 6405 Spectrophotometer with a $1 \mathrm{~cm}$ quartz cell. ${ }^{1} \mathrm{H}$ NMR spectra were measured on Bruker $(300 \mathrm{MHz})$ and TMS was used as internal standard. 


\subsection{Preparation of (2-Phenyl-3,4-dihydro-quinazolin-4-yloxy)-acetic acid $\left(\mathbf{L}_{1}\right)$}

To a solution ester $(1)(1.0 \mathrm{mmol})$ in methyl alcohol $(30 \mathrm{ml})$, was added Potassium hydroxide $(0.112 \mathrm{~g}$, $2.0 \mathrm{mmol}$ ) solution in $10 \mathrm{ml} \mathrm{H}_{2} \mathrm{O}$. The reaction mixture was stirred at RT for $4 \mathrm{~h}$. till complete consumption of the ester (monitored by TLC). The reaction mixture was diluted with water and acidified by Conc.HCl. The separated precipitate was filtered off and washed several times with water and dried. The resultant white product with crystalized from ethanol to give the carboxylic acid (2) in pure state. (Scheme 1)<smiles>CCOC(=O)COc1nc(-c2ccccc2)nc2ccccc12</smiles>

\subsection{Preparation of All complexes with ligand $\left(\mathrm{L}_{1}\right)$}

Metal complexes were prepared by dissolving $(0.02 \mathrm{~mol})$ of ligand $(0.560 \mathrm{gm})$ in $20 \mathrm{ml}$ methanol, then (0.01 mol) amounts of the metal (0.25-0.3) $\mathrm{mg}$ were dissolved in $10 \mathrm{ml}$ methanol. The two methanolic solutions were mixed, then adjusted $\mathrm{pH}$ of the mixture at 8 . The solution was left in air until methanol was completely evaporated. The precipitate metal complexes were filtered off, washed with acetone and drying in a desiccator. Complexes with 1:2 $\left(\mathrm{M}: \mathrm{L}_{1}\right)$ ratios were obtained from reaction of ligand and $\mathrm{M}\left(\mathrm{NO}_{3}\right)_{2}$ analyses as $\mathrm{ML}_{2}$ compound.

\subsection{Antimicrobial investigation}

The synthetic compounds dissolved in DMSO were tested by paper-disc agar-plate method [12], using three concentrations 30, 15 and $100 \mu \mathrm{g}$ per disk against two reference bacterial strains (Escherichia coli NCMB 11943; Staphylococcus aureus NCMB 6571), one clinical culture (Candida albicans). Nutrient agar was used for testing the bacterial strains and potato dextrose agar was used for fungi. The experiment was performed in triplicate, negative controls (DMSO loaded discs) and positive controls (4 commercial antibiotic discs, Oxoid) were included. Inhibitory activity was recorded by measuring the clear zone diameter after incubation at $37^{\circ} \mathrm{C}$ for $24 \mathrm{~h}$. for bacteria and at $30^{\circ} \mathrm{C}$ for $48 \mathrm{~h}$. for Candida.

\section{Results and discussion}

\subsection{Elemental analysis}

The elemental analysis results are summarized in (Table1).These results are in good agreement with the proposed formula. The melting points of the complexes are higher than that of the free ligand, revealing that the complexes are much more stable than ligand.

Table 1: Analytical and physical data of $\mathrm{L}_{1}$ and its metal complexes.

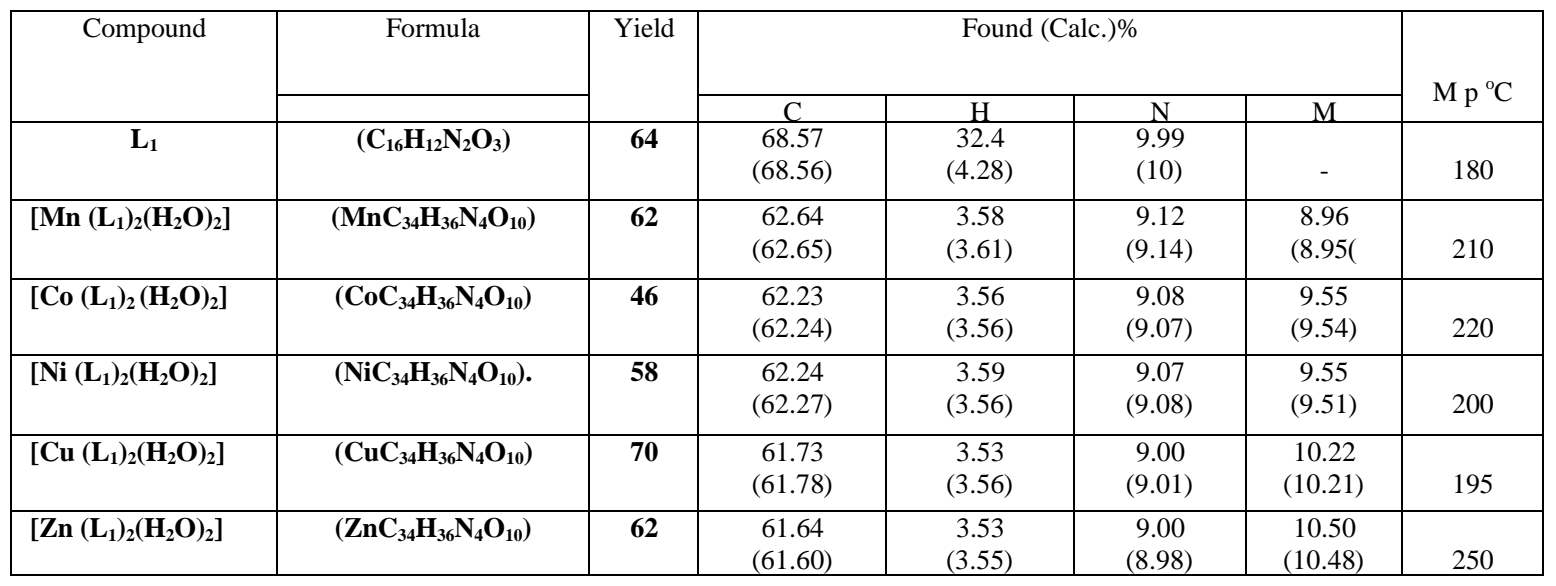

\subsection{Infrared spectra}

The IR data for $\mathrm{L}_{1}$ and its complexes are listed in (Table 2). The IR spectra of the complexes were compared with those of the free ligand in order to determine the coordination sites that may be involved in chelation. There are some guide peaks, in the spectra of the ligand, which are useful in achieving this goal. The position and/or the intensities of these peaks are expected to be changed upon chelation. These guide peaks are listed in 
Synthesis and characterization of some metal complexes of 2-Phenyl-3,4-dihydro-quinazolin-4-yloxy..

Table 2. The IR spectrum showed different signals at: $1716(\mathrm{C}=\mathrm{O}$ acid $), 1563-1577$ for $\left(\mathrm{COO}_{\text {asym }}\right), 1483-$ $1491($ COOsym $)$ and 1664-1675(C=O amideIndeed, The difference $\Delta\left(\Delta=\right.$ vas.COO - vs .COO) $82-94 \mathrm{~cm}^{-1}$ indicate bidentate metal carboxylate. From the IR spectra, it is concluded that L1 behaves as neutral bidentate ligand and binds to the metal ions through two protonated carboxylate $\mathrm{O}$ groups $[13,14]$.

Table 2: IR bands of the ligand $\mathrm{L}_{1}$ and its complexes

\begin{tabular}{|c|c|c|c|c|c|c|c|}
\hline Compound & $\begin{array}{c}v(\mathrm{COO}) \\
\text { (asymmetric) }\end{array}$ & $\mathrm{v}(\mathrm{COO})$ (symmetric) & $\Delta$ & $\begin{array}{c}v(\mathrm{C}=\mathrm{O}) \\
(\text { Acid })\end{array}$ & $\begin{array}{l}v(\mathrm{C}=\mathrm{O}) \\
(\text { Amide })\end{array}$ & $\begin{array}{l}\mathrm{v}(\mathrm{M}-\mathrm{O}) \\
(\mathrm{COO})\end{array}$ & $\begin{array}{c}(\mathrm{M}-\mathrm{O}) \\
(\mathrm{H} 2 \mathrm{O})\end{array}$ \\
\hline $\mathbf{L}_{1}$ & 1563 & 1391 & 172 & 1716 & 1675 & -- & -- \\
\hline$\left[\mathrm{Mn}\left(\mathrm{L}_{1}\right)_{2}\left(\mathrm{H}_{2} \mathrm{O}\right)_{2}\right]$ & 1566 & 1483 & 83 & - & 1671 & 430 & 594 \\
\hline$\left[\mathrm{Co}\left(\mathrm{L}_{1}\right)_{2}\left(\mathrm{H}_{2} \mathrm{O}\right)_{2}\right]$ & 1577 & 1483 & 94 & - & 1664 & 458 & 615 \\
\hline$\left[\mathrm{Ni}\left(\mathrm{L}_{1}\right)_{2}\left(\mathrm{H}_{2} \mathrm{O}\right)_{2}\right]$ & 1575 & 1489 & 86 & - & 1670 & 454 & 617 \\
\hline$\left[\mathrm{Cu}\left(\mathrm{L}_{1}\right)_{2}\left(\mathrm{H}_{2} \mathrm{O}\right)_{2}\right]$ & 1567 & 1485 & 82 & - & 1671 & 457 & 537 \\
\hline$\left[\mathrm{Zn}(\mathrm{L1})_{2}\left(\mathrm{H}_{2} \mathrm{O}\right)_{2}\right]$ & 1566 & 1486 & 80 & - & 1672 & 459 & 538 \\
\hline
\end{tabular}

\subsection{ESR analysis}

ESR spectra of powdered samples of the complexes of $\mathrm{Cu}^{2+}$ are similar and exhibit isotropic spectra with intense broad signals with no hyperfine structure at $300 \mathrm{~K}$. The $\mathrm{Cu}^{2+}$ complex exhibits an axial signal with two $g$ values $(\mathrm{g} \|=2.211, \mathrm{~g} \perp=2.049)$ at $300 \mathrm{~K}$. In this complex, the lowest $\mathrm{g}$ value is $>2.04$ and this indicates that the copper(II) ion is present in an axial symmetry with all the principle axes aligned parallel. This would be consistent with a distorted octahedral stereochemistry (Fig.2).

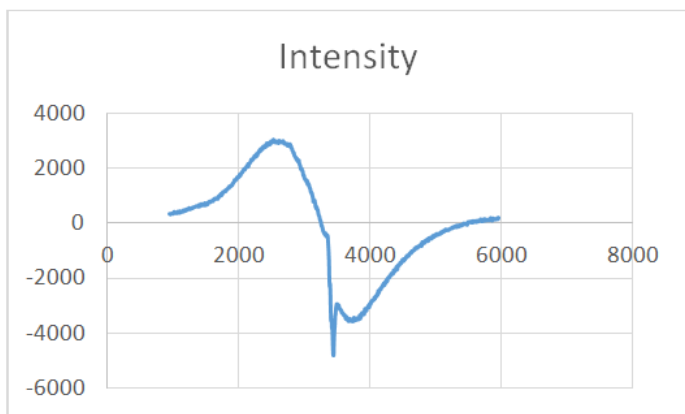

Fig.2. ESR spectra of copper (II) complexes at $300 \mathrm{~K}(\mathrm{~A})$ in the solid state

\subsection{NMR spectra}

The structure assignment of carboxylic acid (2-phenyl-3,4-dihydro-quinazolin-4-yloxy) acetic acid $\left(\mathrm{L}_{1}\right)$ is based on ${ }^{1} \mathrm{H}$ and ${ }^{13} \mathrm{C}$ NMR spectroscopy, as well as physicochemical analysis, Fig. (3,4). The ${ }^{1} \mathrm{H}$ NMR spectrum of $\left(\mathrm{L}_{1}\right)$ in DMSO (Fig. 3) showed singlet signal at $13.22 \mathrm{ppm}$ for $\mathrm{OH}$ group, multiplet signal between $8.50 \mathrm{ppm}$ and $7.54 \mathrm{ppm}$ for nine aromatic protons, singlet signal $5.24 \mathrm{ppm}$ for $\mathrm{OCH}_{2}$ group. Also, structure $\left(\mathrm{L}_{1}\right)$ was confirmed by ${ }^{13} \mathrm{C}$ NMR spectrum (Fig. 4). Signal for CO group appeared at $169.9 \mathrm{ppm}$, signals for C-Ar appeared at 166.1, 159.0, 151.8, 137.6, 135.0, 131.4, 129.1, 128.5, 128.2, 127.9, 123.7 and $114.7 \mathrm{ppm}$ and signal at 63.9 ppm for $\mathrm{OCH}_{2}$ group. (Fig. 5) shows the ${ }^{1} \mathrm{H}-\mathrm{NMR}$ spectrum

of $\mathrm{Zn}$ (II) complex which was carried out in DMSO-d6as a solvent. Upon comparison with the free ligand, the signal observed at $13.22 \mathrm{ppm}$ can be assigned to the carboxylate $\mathrm{OH}$. This signal disappears in the spectrum of the $\left[\mathrm{Zn}(\mathrm{L} 1)_{2}\right] .2 \mathrm{H}_{2} \mathrm{O}$ complex, which confirms the coordination of $\mathrm{L}_{1}$ ligand to the $\mathrm{M}$ (II) ions through the deprotonated carboxylic $\mathrm{O}$ group.

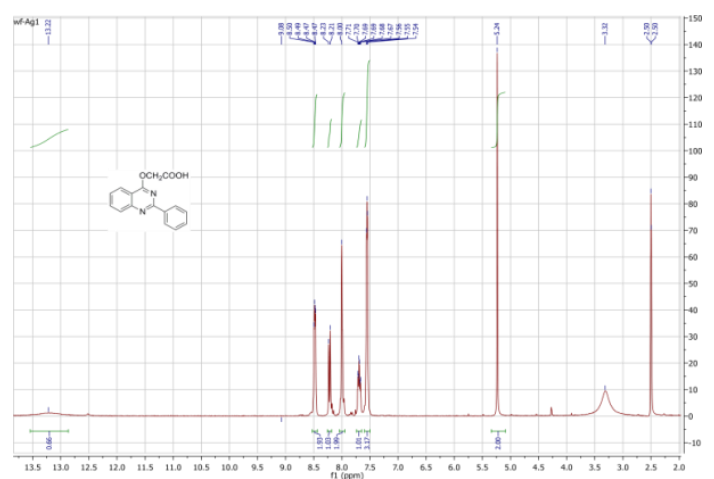

Fig 3: $\mathrm{H}^{1}-\mathrm{NMR}$ spectrum data of the ligand $\left(\mathrm{L}_{1}\right)$ 


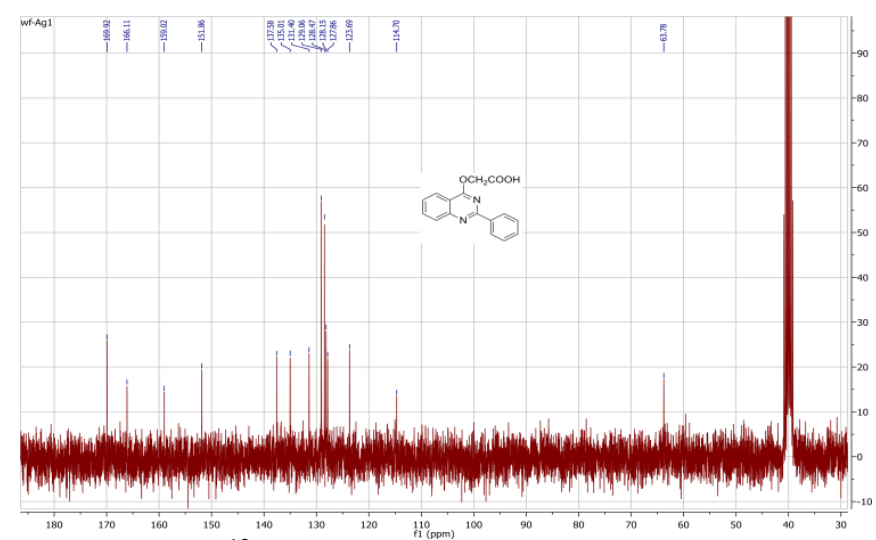

Fig 4: $\mathrm{C}^{13} \mathrm{NMR}$ spectrum data of the ligand $\left(\mathrm{L}_{1}\right)$

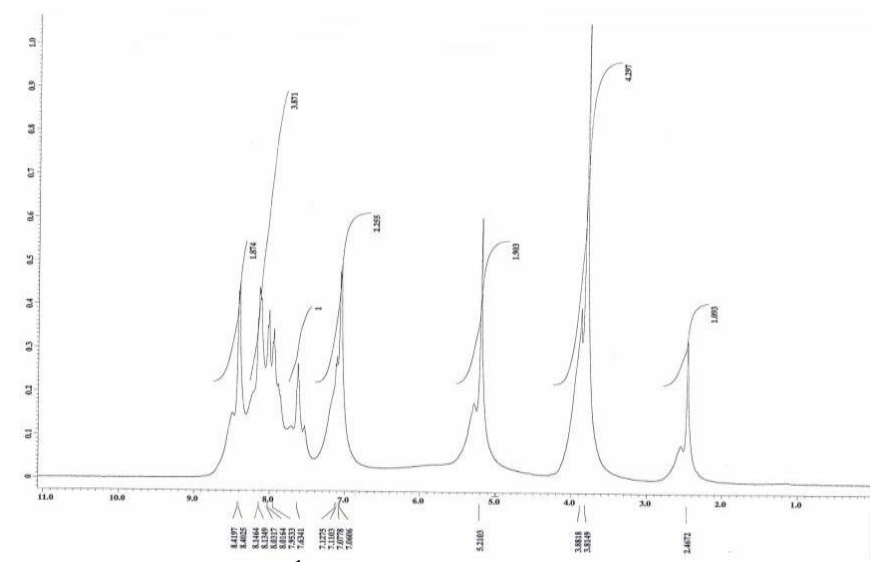

Fig 5: $\mathrm{H}^{1}-\mathrm{NMR}$ spectrum data of $\mathrm{ZnL}_{1}$

\subsection{Thermogravimetric analysis (TG)}

In the present investigation, the heating rates were controlled at $100 \mathrm{C} \mathrm{min}^{-1}$ under nitrogen atmosphere and the weight loss was measured from ambient temperature up to $800 \mathrm{C}$. The data are listed in (Table 4). The weight losses for each chelate were calculated within the corresponding temperature ranges. The different thermodynamic parameters are listed in (Table 5).

The thermal decomposition of $\left(\mathrm{C}_{16} \mathrm{H}_{12} \mathrm{~N}_{2} \mathrm{O}_{3}\right)\left(\mathrm{L}_{1}\right)$ occurs at one steps. The first degradation step take place in the range of 29.22-799.07C, which assigned to loss $\mathrm{N}_{2}, 3(\mathrm{CO})$ and $6\left(\mathrm{C}_{2} \mathrm{H}_{2}\right)$ with the weight loss $99.1 \%$ and the calculated value is $95.7 \%$. The final result polluted with some carbon residue.

The thermal decomposition of $\left(\mathrm{MnC}_{34} \mathrm{H}_{36} \mathrm{~N}_{4} \mathrm{O}_{10}\right)$ occurs at five steps. The first degradation step take place in the range of $34.07-59.50{ }^{\circ} \mathrm{C}$ and it is corresponds to the eliminated of one molecule of water due to a weight loss of $2.516 \%$ in good matching with theoretical value $2.5 \%$. The second step fall in the range of $60.03-$ $191.32{ }^{\circ} \mathrm{C}$, which assigned to loss $3\left(\mathrm{NH}_{3}\right)$ with the weight loss $7.106 \%$ and the calculated value is $7.5 \%$. The third step fall in the range of $192.23-333.05{ }^{\circ} \mathrm{C}$, which assigned to $\mathrm{NH}_{3}$ and $5(\mathrm{CO})$ with the weight loss $24.182 \%$ and the calculated value is $25 \%$. The fourth step fall in the range of $333.05-441.04{ }^{\circ} \mathrm{C}$, which assigned to $\mathrm{CO}_{2}$ and $2\left(\mathrm{C}_{2} \mathrm{H}_{2}\right)$ with the weight loss $21.185 \%$ and the calculated value is $20.4 \%$. The fifth step fall in the range of 441.04-799.49 ${ }^{\circ} \mathrm{C}$, which assigned to $3\left(\mathrm{CH}_{4}\right)$ and $2\left(\mathrm{C}_{2} \mathrm{H}_{2}\right)$ with the weight loss $26.780 \%$ and the calculated value is $26.67 \%$.The $18.231 \% \mathrm{MnO}$ is the final product remains stable till $800{ }^{\circ} \mathrm{C}$ polluted with some carbon atoms.

The thermal decomposition of $\left(\mathrm{CoC}_{34} \mathrm{H}_{36} \mathrm{~N}_{4} \mathrm{O}_{10}\right)$ occurs at four steps. The first degradation step take place in the range of $22.60-102.64{ }^{\circ} \mathrm{C}$ and it is corresponds to the eliminated of 2 molecules of water due to a weight loss of $5.079 \%$ in good matching with theoretical value $5.00 \%$. The second step fall in the range of 103.60-336.14 ${ }^{\circ} \mathrm{C}$, which assigned to loss $4(\mathrm{CO}), 4\left(\mathrm{NH}_{3}\right)$ and $\mathrm{CO}_{2}$ with the weight loss $32.918 \%$ and the calculated value is $32.8 \%$. The third step fall in the range of $336.14-474.45{ }^{\circ} \mathrm{C}$, which assigned to $\mathrm{CO}$ and $3\left(\mathrm{CH}_{4}\right)$ with the weight loss $18.274 \%$ and the calculated value is $16.6 \%$. The fourth step fall in the range of 475.48-799.89 ${ }^{\circ} \mathrm{C}$, which assigned to $\mathrm{CH}_{4}$ and $2\left(\mathrm{C}_{2} \mathrm{H}_{2}\right)$ with the weight loss $19.543 \%$ and the calculated value is $17.76 \%$. The $24.186 \% \mathrm{CoO}$ is the final product remains stable till $800{ }^{\circ} \mathrm{C}$ polluted with some carbon atoms.

The thermal decomposition of $\left(\mathrm{NiC}_{34} \mathrm{H}_{36} \mathrm{~N}_{4} \mathrm{O}_{10}\right)$ occurs at three steps. The first degradation step take place in the range of $29.18-100.99{ }^{\circ} \mathrm{C}$ and it is corresponds to the eliminated of one molecule of water due to a weight loss of $2.762 \%$ in good matching with theoretical value $2.56 \%$. The second step fall in the range of 100.99-397.37 ${ }^{\circ} \mathrm{C}$, which assigned to loss $5(\mathrm{CO}), 4\left(\mathrm{NH}_{3}\right), \mathrm{CO}_{2}, \mathrm{CH}_{4}$ and $4\left(\mathrm{C}_{2} \mathrm{H}_{2}\right)$ with the weight loss $54.464 \%$ 
and the calculated value is $54.4 \%$. The third step fall in the range of $397.37-799.85{ }^{\circ} \mathrm{C}$, which assigned to $2\left(\mathrm{C}_{2} \mathrm{H}_{2}\right)$ and $\mathrm{CH}_{4}$ with the weight loss $22.756 \%$ and the calculated value is $21.9 \%$. The $20.018 \% \mathrm{NiO}$ is the final product remains stable till $800{ }^{\circ} \mathrm{C}$ polluted with some carbon atoms.

The thermal decomposition of $\left(\mathrm{CuC}_{34} \mathrm{H}_{36} \mathrm{~N}_{4} \mathrm{O}_{10}\right)$ occurs at five steps. The first degradation step take place in the range of $36.76-118.63{ }^{\circ} \mathrm{C}$ and it is corresponds to the eliminated of one molecule of water due to a weight loss of $1.832 \%$ in good matching with theoretical value $2.5 \%$. The second step fall in the range of $119.81-201.56{ }^{\circ} \mathrm{C}$, which assigned to loss $\mathrm{CO}$ with the weight loss $3.975 \%$ and the calculated value is $4.00 \%$. The third step fall in the range of 202.49-351.86 ${ }^{\circ} \mathrm{C}$, which assigned to $\mathrm{CO}, 4\left(\mathrm{NH}_{3}\right)$ and $\mathrm{CO}_{2}$ with the weight loss $21.697 \%$ and the calculated value is $21.2 \%$. The fourth step fall in the range of $351.86-447.06{ }^{\circ} \mathrm{C}$, which assigned to $\mathrm{CO}_{2}$ and $\mathrm{CO}$ with the weight loss $12.646 \%$ and the calculated value is $13.58 \%$. The fifth step fall in the range of $448.05-799.84{ }^{\circ} \mathrm{C}$, which assigned to $3\left(\mathrm{CH}_{4}\right)$ and $4\left(\mathrm{C}_{2} \mathrm{H}_{2}\right)$ with the weight loss $32.91 \%$ and the calculated value is $33.9 \%$.The $26.94 \% \mathrm{CuO}$ is the final product remains stable till $800{ }^{\circ} \mathrm{C}$ and 18 unoxidized carbon atoms.

The thermal decomposition of $\left(\mathrm{ZnC}_{34} \mathrm{H}_{36} \mathrm{~N}_{4} \mathrm{O}_{10}\right)$ occurs at five steps. The first degradation step take place in the range of $43.43-108.53{ }^{\circ} \mathrm{C}$ and it is corresponds to the eliminated of half molecule of water due to a weight loss of $1.199 \%$ in good matching with theoretical value $1.29 \%$. The second step fall in the range of 109.18-308.26 ${ }^{\circ} \mathrm{C}$, which assigned to loss $4\left(\mathrm{NH}_{3}\right)$ and $\mathrm{CO}_{2}$ with the weight loss $16.679 \%$ and the calculated value is $16.24 \%$. The third step fall in the range of $308.26-377.30{ }^{\circ} \mathrm{C}$, which assigned to $2 \mathrm{CO}$ with the weight loss $10.916 \%$ and the calculated value is $9.79 \%$. The fourth step fall in the range of $377.30-548.84{ }^{\circ} \mathrm{C}$, which assigned to $\mathrm{CO}_{2}$ and $\mathrm{CO}$ with the weight loss $14.598 \%$ and the calculated value is $13.9 \%$. The fifth step fall in the range of $549.01-799.91{ }^{\circ} \mathrm{C}$, which assigned to $4\left(\mathrm{CH}_{4}\right)$ and $2\left(\mathrm{C}_{2} \mathrm{H}_{2}\right)$ with the weight loss $28.829 \%$ and the calculated value is $26.7 \%$.The $27.779 \% \mathrm{ZnO}$ is the final product remains stable till $800{ }^{\circ} \mathrm{C}$ and 21 unoxidized carbon atoms. Reported data dealing in the thermal analysis investigation within nitrogen atmosphere indicate that, the $\mathrm{Zn}$ (II) complex decompose to give oxide contaminated with few carbon atoms as final products, this reason because of no sufficiently of oxygen atoms help to evolved carbon as carbon monoxide or dioxide.

The different thermodynamic parameters were calculated upon Coats-Redfern [15] and Horowitz-Metzger [16] methods and listed in Table 4. The activation energies of decomposition found to be in the range $1.00 \times 10^{5}-$ $9.58 \times 10^{4} \mathrm{kJmol}^{-1}$. The high values of the activation energies reflect the thermal stability of the complexes. The entropy of activation found to have negative values in all the complexes, which indicate that the decomposition reactions proceed with a lower rate than the normal ones. On another meaning the thermal decomposition process of all complexes are non-spontaneous, i.e, the complexes are thermally stable. The correlation coefficients of the Arhenius plots of the thermal decomposition steps found to lie in the range 0.7758 to 0.9963 , showing a good fit with linear function.

Table 4 : Thermodynamic data of the thermal decomposition of ligand $\left(\mathrm{L}_{1}\right)$ and its complexes

\begin{tabular}{|c|c|c|c|c|c|c|}
\hline Comp. ${ }^{a}$ & TG range $(\mathrm{C})$ & DTA (C) & Stage & $\begin{array}{c}\text { Mass loss } \\
\text { \%found(calc.) }\end{array}$ & Assignment & $\begin{array}{l}\text { Metallic } \\
\text { residue }\end{array}$ \\
\hline $\mathrm{L}_{1}\left(\mathrm{C}_{16} \mathrm{H}_{12} \mathrm{~N}_{2} \mathrm{O}_{3}\right)$ & $29.22-799.07$ & 414.145 & $1^{\mathrm{st}}$ & $99.1(95.7)$ & $\mathrm{N}_{2}, 3(\mathrm{CO}), 6\left(\mathrm{C}_{2} \mathrm{H}_{2}\right)$ & $\begin{array}{l}\text { Carbon } \\
\text { residue }\end{array}$ \\
\hline \multirow{5}{*}[\mathbf{Mn}(\mathbf{L}_{1})_{2}(\mathbf{H}_{2}\mathbf{O})_{2}]{} & $34.07-59.50$ & 47.2897 & $1^{\mathrm{st}}$ & $2.516(2.5)$ & $\mathrm{H}_{2} \mathrm{O}$ & \multirow[t]{5}{*}{$\mathrm{MnO}$} \\
\hline & $60.03-191.32$ & 120.124 & $2^{\text {nd }}$ & $7.106(7.5)$ & $3\left(\mathrm{NH}_{3}\right)$ & \\
\hline & $192.23-333.05$ & 266.893 & $3^{\text {rd }}$ & $24.182(25)$ & $\mathrm{NH}_{3}, 5(\mathrm{CO})$ & \\
\hline & $333.05-441.04$ & 381.255 & $4^{\text {th }}$ & $21.185(20.4)$ & $\mathrm{CO}_{2,} 2\left(\mathrm{C}_{2} \mathrm{H}_{2}\right)$ & \\
\hline & 441.04-799.49 & 604.322 & $5^{\text {th }}$ & $26.780(26.67)$ & $3\left(\mathrm{CH}_{4}\right), 2\left(\mathrm{C}_{2} \mathrm{H}_{2}\right)$ & \\
\hline \multirow{4}{*}[\mathrm{Co}(\mathbf{L}_{1})_{2}(\mathbf{H}_{2}\mathbf{O})_{2}]{} & $22.60-102.64$ & 64.666 & $1^{\mathrm{st}}$ & $5.079(5.00)$ & $2 \mathrm{H}_{2} \mathrm{O}$ & \multirow[t]{4}{*}{$\mathrm{CoO}$} \\
\hline & 103.60-336.14 & 270.7 & $2^{\text {nd }}$ & $32.918(32.8)$ & $4(\mathrm{CO}), 4\left(\mathrm{NH}_{3}\right), \mathrm{CO}_{2}$ & \\
\hline & $336.14-474.45$ & 428.09 & $3^{\text {rd }}$ & 18.274 (16.6) & $\mathrm{CO}, 3\left(\mathrm{CH}_{4}\right)$ & \\
\hline & $475.48-799.89$ & 637.685 & $4^{\text {th }}$ & $19.543(17.76)$ & $\mathrm{CH}_{4}, 2\left(\mathrm{C}_{2} \mathrm{H}_{2}\right)$ & \\
\hline \multirow{3}{*}[\mathbf{Ni}(\mathbf{L}_{1})_{2}(\mathbf{H}_{2}\mathbf{O})_{2}]{} & 29.18-100.99 & 67.1966 & $1^{\mathrm{st}}$ & $2.762(2.56)$ & $\mathrm{H}_{2} \mathrm{O}$ & \multirow[t]{3}{*}{$\mathrm{NiO}$} \\
\hline & $100.99-397.37$ & 271.614 & $2^{\text {nd }}$ & $54.464(54.4)$ & $\begin{array}{c}5(\mathrm{CO}), 4\left(\mathrm{NH}_{3}\right), \mathrm{CO}_{2}, \\
\mathrm{CH}_{4} 4\left(\mathrm{C}_{2} \mathrm{H}_{2}\right)\end{array}$ & \\
\hline & $397.37-799.85$ & 598.61 & $3^{\text {rd }}$ & $22.756(21.9)$ & $2\left(\mathrm{C}_{2} \mathrm{H}_{2}\right), \mathrm{CH}_{4}$ & \\
\hline \multirow{5}{*}[\mathrm{Cu}(\mathbf{L}_{1})_{2}(\mathbf{H}_{2}\mathbf{O})_{2}]{} & $36.76-118.63$ & 86.5487 & $1^{\mathrm{st}}$ & $1.832(2.5)$ & $\mathrm{H}_{2} \mathrm{O}$ & \multirow[t]{5}{*}{$\mathrm{CuO}$} \\
\hline & $119.81-201.56$ & 169.376 & $2^{\text {nd }}$ & $3.975(4.00)$ & $\mathrm{CO}$ & \\
\hline & $202.49-351.86$ & 283.16 & $3^{\text {rd }}$ & $21.697(21.2)$ & $\mathrm{CO}, 4\left(\mathrm{NH}_{3}\right), \mathrm{CO}_{2}$ & \\
\hline & $351.86-447.06$ & 400.473 & $4^{\text {th }}$ & $12.646(13.58)$ & $\mathrm{CO}, \mathrm{CO}_{2}$ & \\
\hline & $448.05-799.84$ & 623.945 & $5^{\text {th }}$ & 32.91 (33.9) & $3\left(\mathrm{CH}_{4}\right), 4\left(\mathrm{C}_{2} \mathrm{H}_{2}\right)$ & \\
\hline \multirow{5}{*}[\mathbf{Zn}(\mathbf{L}_{1})_{2}(\mathbf{H}_{2}\mathbf{O})_{2}]{} & $43.43-108.53$ & 82.7016 & $1^{\mathrm{st}}$ & $1.199(1.29)$ & $0.5\left(\mathrm{H}_{2} \mathrm{O}\right)$ & \multirow[t]{5}{*}{$\mathrm{ZnO}$} \\
\hline & $109.18-308.26$ & 256.178 & $2^{\text {nd }}$ & $16.679(16.24)$ & $4\left(\mathrm{NH}_{3}\right), \mathrm{CO}_{2}$ & \\
\hline & $308.26-377.30$ & 346.404 & $3^{\text {rd }}$ & $10.916(9.79)$ & $2(\mathrm{CO})$ & \\
\hline & $377.30-548.84$ & 463.07 & $4^{\text {th }}$ & $14.598(13.9)$ & $\mathrm{CO}, \mathrm{CO}_{2}$ & \\
\hline & $549.01-799.91$ & 675.774 & $5^{\text {th }}$ & $28.829(26.7)$ & $4\left(\mathrm{CH}_{4}\right), 2\left(\mathrm{C}_{2} \mathrm{H}_{2}\right)$ & \\
\hline
\end{tabular}


Synthesis and characterization of some metal complexes of 2-Phenyl-3,4-dihydro-quinazolin-4-yloxy..

Table 5 : Thermodynamic data of the thermal decomposition of ligand $\left(\mathrm{L}_{1}\right)$ and its complexes

\begin{tabular}{|c|c|c|c|c|c|c|c|c|}
\hline & Stage & Method & E & $A$ & $-\Delta S$ & $\Delta \mathbf{H}$ & $\Delta G$ & $\mathbf{R}$ \\
\hline \multirow[t]{15}{*}[\mathrm{Mn}(\mathrm{L}_{1})_{2}(\mathrm{H}_{2}\mathbf{O})_{2}]{} & $1^{\text {st }}$ & $\mathrm{CR}$ & $1.48 \mathrm{E}+05$ & $3.09 E+03$ & $1.79 \mathrm{E}+02$ & $1.45 E+05$ & $2.02 E+05$ & 0.97374 \\
\hline & & HM & $1.54 \mathrm{E}+04$ & $9.94 \mathrm{E}-01$ & $2.46 \mathrm{E}+02$ & $1.28 \mathrm{E}+04$ & $9.15 \mathrm{E}+04$ & 0.9785 \\
\hline & & Average & $8.16 \mathrm{E}+04$ & $1.55 E+03$ & $2.12 E+02$ & $7.89 \mathrm{E}+04$ & $1.47 \mathrm{E}+05$ & 0.97612 \\
\hline & $2^{\text {nd }}$ & CR & $2.03 E+04$ & $3.99 \mathrm{E}+00$ & $2.36 \mathrm{E}+02$ & $1.70 E+04$ & $1.10 E+05$ & 0.93397 \\
\hline & & HM & $3.56 \mathrm{E}+04$ & $2.47 \mathrm{E}+02$ & $2.01 \mathrm{E}+02$ & $3.23 \mathrm{E}+04$ & $1.12 E+05$ & 0.9449 \\
\hline & & Average & $2.79 \mathrm{E}+04$ & $1.25 E+02$ & $2.19 \mathrm{E}+02$ & $2.47 \mathrm{E}+04$ & $1.11 \mathrm{E}+05$ & 0.939435 \\
\hline & $3^{\text {th }}$ & $\mathrm{CR}$ & $8.20 E+04$ & $1.85 E+05$ & $1.49 \mathrm{E}+02$ & $7.75 E+04$ & $1.58 \mathrm{E}+05$ & 0.99185 \\
\hline & & HM & $9.58 \mathrm{E}+04$ & $1.21 \mathrm{E}+07$ & $1.14 \mathrm{E}+02$ & $9.13 E+04$ & $1.53 E+05$ & 0.99798 \\
\hline & & Average & $8.89 \mathrm{E}+04$ & $6.13 E+06$ & $1.32 \mathrm{E}+02$ & $8.44 E+04$ & $1.55 E+05$ & 0.994915 \\
\hline & $4^{\text {th }}$ & CR & $1.21 \mathrm{E}+05$ & $1.64 E+07$ & $1.13 \mathrm{E}+02$ & $1.16 \mathrm{E}+05$ & $1.90 E+05$ & 0.96821 \\
\hline & & HM & $1.34 \mathrm{E}+05$ & $3.26 \mathrm{E}+08$ & $8.85 E+01$ & $1.29 \mathrm{E}+05$ & $1.87 E+05$ & 0.96041 \\
\hline & & Average & $1.28 \mathrm{E}+05$ & $1.71 \mathrm{E}+08$ & $1.01 \mathrm{E}+02$ & $1.22 \mathrm{E}+05$ & $1.88 \mathrm{E}+05$ & 0.96431 \\
\hline & $5^{\text {th }}$ & $\mathrm{CR}$ & $4.04 \mathrm{E}+04$ & $2.72 \mathrm{E}-01$ & $2.65 \mathrm{E}+02$ & $3.31 \mathrm{E}+04$ & $2.65 \mathrm{E}+05$ & 0.63789 \\
\hline & & HM & $5.62 \mathrm{E}+04$ & $3.23 E+00$ & $2.44 \mathrm{E}+02$ & $4.89 \mathrm{E}+04$ & $2.63 \mathrm{E}+05$ & 0.72114 \\
\hline & & Average & $4.83 E+04$ & $1.75 E+00$ & $2.54 \mathrm{E}+02$ & $4.10 E+04$ & $2.64 \mathrm{E}+05$ & 0.679515 \\
\hline \multirow[t]{15}{*}[\mathrm{Co}(\mathrm{L}_{1})_{2}(\mathrm{H}_{2}\mathrm{O})_{2}]{} & $1^{\text {st }}$ & CR & $6.19 \mathrm{E}+04$ & $3.24 E+07$ & $1.02 E+02$ & $5.91 \mathrm{E}+04$ & $9.36 \mathrm{E}+04$ & 0.9731 \\
\hline & & $\mathrm{HM}$ & $6.77 \mathrm{E}+04$ & $3.52 \mathrm{E}+08$ & $8.23 E+01$ & $6.49 \mathrm{E}+04$ & $9.27 \mathrm{E}+04$ & 0.95985 \\
\hline & & Average & $6.48 \mathrm{E}+04$ & $1.92 \mathrm{E}+08$ & $9.23 \mathrm{E}+01$ & $6.20 \mathrm{E}+04$ & $9.32 \mathrm{E}+04$ & 0.966475 \\
\hline & $2^{\text {nd }}$ & CR & $3.80 \mathrm{E}+04$ & $1.42 E+03$ & $1.90 \mathrm{E}+02$ & $3.34 \mathrm{E}+04$ & $1.37 \mathrm{E}+05$ & 0.94339 \\
\hline & & $\mathrm{HM}$ & $1.15 \mathrm{E}+05$ & $9.45 \mathrm{E}+08$ & $7.81 \mathrm{E}+01$ & $1.11 \mathrm{E}+05$ & $1.53 \mathrm{E}+05$ & 0.95189 \\
\hline & & Average & $7.67 \mathrm{E}+04$ & $4.72 \mathrm{E}+08$ & $1.34 \mathrm{E}+02$ & $7.22 \mathrm{E}+04$ & $1.45 \mathrm{E}+05$ & 0.94764 \\
\hline & $3^{\text {th }}$ & CR & $1.12 \mathrm{E}+05$ & $5.41 \mathrm{E}+05$ & $1.42 \mathrm{E}+02$ & $1.06 \mathrm{E}+05$ & $2.06 \mathrm{E}+05$ & 0.86684 \\
\hline & & HM & $1.32 \mathrm{E}+05$ & $3.78 \mathrm{E}+07$ & $1.07 \mathrm{E}+02$ & $1.26 \mathrm{E}+05$ & $2.01 \mathrm{E}+05$ & 0.91022 \\
\hline & & Average & $1.22 \mathrm{E}+05$ & $1.92 \mathrm{E}+07$ & $1.25 \mathrm{E}+02$ & $1.16 \mathrm{E}+05$ & $2.03 \mathrm{E}+05$ & 0.88853 \\
\hline & $4^{\text {th }}$ & CR & $1.06 \mathrm{E}+05$ & $5.14 \mathrm{E}+03$ & $1.83 \mathrm{E}+02$ & $9.88 \mathrm{E}+04$ & $2.55 \mathrm{E}+05$ & 0.95498 \\
\hline & & HM & $1.22 \mathrm{E}+05$ & $9.50 \mathrm{E}+04$ & $1.58 \mathrm{E}+02$ & $1.15 \mathrm{E}+05$ & $2.50 \mathrm{E}+05$ & 0.94567 \\
\hline & & Average & $1.14 \mathrm{E}+05$ & $5.01 \mathrm{E}+04$ & $1.70 \mathrm{E}+02$ & $1.07 E+05$ & $2.52 \mathrm{E}+05$ & 0.950325 \\
\hline & $5^{\text {th }}$ & $\mathrm{CR}$ & $2.35 \mathrm{E}+05$ & $6.52 E+09$ & $6.72 \mathrm{E}+01$ & $2.26 \mathrm{E}+05$ & $2.94 \mathrm{E}+05$ & 0.97166 \\
\hline & & $\mathrm{HM}$ & $2.50 \mathrm{E}+05$ & $3.90 \mathrm{E}+10$ & $5.23 \mathrm{E}+01$ & $2.42 \mathrm{E}+05$ & $2.95 \mathrm{E}+05$ & 0.97551 \\
\hline & & Average & $2.43 \mathrm{E}+05$ & $2.27 \mathrm{E}+10$ & $5.98 \mathrm{E}+01$ & $2.34 \mathrm{E}+05$ & $2.95 \mathrm{E}+05$ & 0.973585 \\
\hline
\end{tabular}




\begin{tabular}{|c|c|c|c|c|c|c|c|c|}
\hline \multirow[t]{12}{*}[\mathrm{Ni}(\mathrm{L}_{1})_{2}(\mathrm{H}_{2}\mathrm{O})_{2}]{} & $1^{\text {st }}$ & CR & $4.84 \mathrm{E}+04$ & $1.19 \mathrm{E}+05$ & $1.49 \mathrm{E}+02$ & $4.56 \mathrm{E}+04$ & $9.62 E+04$ & 0.9963 \\
\hline & & HM & $5.56 \mathrm{E}+04$ & $3.32 \mathrm{E}+06$ & $1.21 \mathrm{E}+02$ & $5.28 \mathrm{E}+04$ & $9.40 \mathrm{E}+04$ & 0.9948 \\
\hline & & Average & $5.20 \mathrm{E}+04$ & $1.72 E+06$ & $1.35 \mathrm{E}+02$ & $4.92 E+04$ & $9.51 \mathrm{E}+04$ & 0.99555 \\
\hline & $2^{\text {nd }}$ & CR & $4.32 E+04$ & $1.00 \mathrm{E}+04$ & $1.73 \mathrm{E}+02$ & $3.87 \mathrm{E}+04$ & $1.33 E+05$ & 0.9889 \\
\hline & & HM & $1.30 \mathrm{E}+05$ & $2.71 \mathrm{E}+10$ & $5.02 \mathrm{E}+01$ & $1.26 \mathrm{E}+05$ & $1.53 \mathrm{E}+05$ & 0.99489 \\
\hline & & Average & $8.67 \mathrm{E}+04$ & $1.35 \mathrm{E}+10$ & $1.12 \mathrm{E}+02$ & $8.22 \mathrm{E}+04$ & $1.43 E+05$ & 0.991895 \\
\hline & $3^{\text {th }}$ & CR & $2.06 \mathrm{E}+05$ & $7.22 \mathrm{E}+09$ & $6.48 \mathrm{E}+01$ & $1.99 \mathrm{E}+05$ & $2.53 \mathrm{E}+05$ & 0.82911 \\
\hline & & $\mathrm{HM}$ & $2.22 \mathrm{E}+05$ & $4.58 \mathrm{E}+11$ & $3.03 E+01$ & $2.15 \mathrm{E}+05$ & $2.40 \mathrm{E}+05$ & 0.77588 \\
\hline & & Average & $2.14 \mathrm{E}+05$ & $2.32 \mathrm{E}+11$ & $4.75 \mathrm{E}+01$ & $2.07 \mathrm{E}+05$ & $2.46 \mathrm{E}+05$ & 0.80247 \\
\hline & $4^{\text {th }}$ & CR & $1.22 \mathrm{E}+05$ & $6.85 \mathrm{E}+03$ & $1.82 \mathrm{E}+02$ & $1.13 \mathrm{E}+05$ & $3.01 \mathrm{E}+05$ & 0.85958 \\
\hline & & $\mathrm{HM}$ & $1.41 \mathrm{E}+05$ & $3.70 \mathrm{E}+04$ & $1.68 \mathrm{E}+02$ & $1.33 \mathrm{E}+05$ & $3.06 \mathrm{E}+05$ & 0.90153 \\
\hline & & Average & $1.31 \mathrm{E}+05$ & $2.19 \mathrm{E}+04$ & $1.75 \mathrm{E}+02$ & $1.23 \mathrm{E}+05$ & $3.04 \mathrm{E}+05$ & 0.880555 \\
\hline \multirow[t]{18}{*}[\mathrm{Cu}(\mathrm{L}_{1})_{2}(\mathrm{H}_{2}\mathrm{O})_{2}]{} & $1^{\text {st }}$ & CR & $4.63 \mathrm{E}+04$ & $4.67 \mathrm{E}+04$ & $1.57 \mathrm{E}+02$ & $4.33 \mathrm{E}+04$ & $9.98 \mathrm{E}+04$ & 0.93374 \\
\hline & & HM & $5.29 \mathrm{E}+04$ & $3.93 E+05$ & $1.39 \mathrm{E}+02$ & $4.99 \mathrm{E}+04$ & $1.00 \mathrm{E}+05$ & 0.93608 \\
\hline & & Average & $4.96 \mathrm{E}+04$ & $2.20 \mathrm{E}+05$ & $1.48 \mathrm{E}+02$ & $4.66 \mathrm{E}+04$ & $9.99 \mathrm{E}+04$ & 0.93491 \\
\hline & $2^{\text {nd }}$ & CR & $2.43 \mathrm{E}+04$ & $1.86 \mathrm{E}+01$ & $2.24 \mathrm{E}+02$ & $2.06 \mathrm{E}+04$ & $1.20 \mathrm{E}+05$ & 0.98145 \\
\hline & & $\mathrm{HM}$ & $5.24 \mathrm{E}+04$ & $8.18 \mathrm{E}+03$ & $1.73 \mathrm{E}+02$ & $4.87 \mathrm{E}+04$ & $1.25 \mathrm{E}+05$ & 0.98318 \\
\hline & & Average & $3.83 E+04$ & $4.10 \mathrm{E}+03$ & $1.99 \mathrm{E}+02$ & $3.47 \mathrm{E}+04$ & $1.23 E+05$ & 0.982315 \\
\hline & $3^{\text {th }}$ & CR & $1.00 \mathrm{E}+05$ & $8.30 \mathrm{E}+06$ & $1.18 \mathrm{E}+02$ & $9.54 \mathrm{E}+04$ & $1.61 \mathrm{E}+05$ & 0.96364 \\
\hline & & HM & $1.13 \mathrm{E}+05$ & $3.11 \mathrm{E}+08$ & $8.75 \mathrm{E}+01$ & $1.09 \mathrm{E}+05$ & $1.57 \mathrm{E}+05$ & 0.94203 \\
\hline & & Average & $1.07 E+05$ & $1.60 \mathrm{E}+08$ & $1.03 E+02$ & $1.02 E+05$ & $1.59 \mathrm{E}+05$ & 0.952835 \\
\hline & $4^{\text {th }}$ & CR & $1.66 \mathrm{E}+05$ & $4.04 E+10$ & $4.86 \mathrm{E}+01$ & $1.61 E+05$ & $1.93 \mathrm{E}+05$ & 0.99078 \\
\hline & & $\mathrm{HM}$ & $1.80 \mathrm{E}+05$ & $6.59 \mathrm{E}+11$ & $2.54 \mathrm{E}+01$ & $1.74 E+05$ & $1.91 \mathrm{E}+05$ & 0.98585 \\
\hline & & Average & $1.73 E+05$ & $3.50 \mathrm{E}+11$ & $3.70 \mathrm{E}+01$ & $1.67 \mathrm{E}+05$ & $1.92 \mathrm{E}+05$ & 0.988315 \\
\hline & $5^{\text {th }}$ & CR & $8.66 \mathrm{E}+04$ & $2.56 \mathrm{E}+02$ & $2.07 \mathrm{E}+02$ & $7.96 \mathrm{E}+04$ & $2.55 \mathrm{E}+05$ & 0.95811 \\
\hline & & $\mathrm{HM}$ & $1.04 \mathrm{E}+05$ & $6.97 \mathrm{E}+03$ & $1.80 \mathrm{E}+02$ & $9.65 E+04$ & $2.49 \mathrm{E}+05$ & 0.95148 \\
\hline & & Average & $9.51 \mathrm{E}+04$ & $3.61 \mathrm{E}+03$ & $1.94 \mathrm{E}+02$ & $8.80 \mathrm{E}+04$ & $2.52 \mathrm{E}+05$ & 0.954795 \\
\hline & $6^{\text {th }}$ & CR & $3.80 \mathrm{E}+05$ & $7.85 \mathrm{E}+03$ & $1.81 \mathrm{E}+02$ & $3.72 E+05$ & $5.57 \mathrm{E}+05$ & 0.98296 \\
\hline & & $\mathrm{HM}$ & $4.01 E+04$ & 8.37E-02 & $2.76 \mathrm{E}+02$ & $3.16 \mathrm{E}+04$ & $3.15 E+05$ & 0.98156 \\
\hline & & Average & $2.10 \mathrm{E}+05$ & $3.93 \mathrm{E}+03$ & $2.28 \mathrm{E}+02$ & $2.02 E+05$ & $4.36 \mathrm{E}+05$ & 0.98226 \\
\hline
\end{tabular}


Synthesis and characterization of some metal complexes of 2-Phenyl-3,4-dihydro-quinazolin-4-yloxy..

\begin{tabular}{|c|c|c|c|c|c|c|c|c|}
\hline \multirow[t]{18}{*}[\mathbf{Zn}(\mathrm{L}_{1})_{2}(\mathbf{H}_{2}\mathbf{O})_{2}]{} & $1^{\text {st }}$ & $\mathrm{CR}$ & $4.06 \mathrm{E}+04$ & $9.92 \mathrm{E}+03$ & $1.70 \mathrm{E}+02$ & $3.77 E+04$ & $9.81 \mathrm{E}+04$ & 0.78797 \\
\hline & & $\mathrm{HM}$ & $4.69 \mathrm{E}+04$ & $5.63 E+04$ & $1.55 \mathrm{E}+02$ & $4.39 \mathrm{E}+04$ & $9.92 \mathrm{E}+04$ & 0.82963 \\
\hline & & Average & $4.37 \mathrm{E}+04$ & $3.31 E+04$ & $1.63 E+02$ & $4.08 \mathrm{E}+04$ & $9.87 \mathrm{E}+04$ & 0.8088 \\
\hline & $2^{\text {nd }}$ & $\mathrm{CR}$ & $2.78 \mathrm{E}+04$ & $3.74 \mathrm{E}+01$ & $2.20 \mathrm{E}+02$ & $2.34 \mathrm{E}+04$ & $1.40 \mathrm{E}+05$ & 0.94431 \\
\hline & & $\mathrm{HM}$ & $8.35 E+04$ & $1.03 E+06$ & $1.35 E+02$ & $7.91 \mathrm{E}+04$ & $1.50 \mathrm{E}+05$ & 0.94823 \\
\hline & & Average & $5.57 \mathrm{E}+04$ & $5.16 \mathrm{E}+05$ & $1.77 \mathrm{E}+02$ & $5.12 \mathrm{E}+04$ & $1.45 \mathrm{E}+05$ & 0.94627 \\
\hline & $3^{\text {th }}$ & $\mathrm{CR}$ & $2.04 \mathrm{E}+05$ & $4.20 \mathrm{E}+03$ & $1.82 \mathrm{E}+02$ & $1.99 \mathrm{E}+05$ & $3.11 \mathrm{E}+05$ & 0.93393 \\
\hline & & $\mathrm{HM}$ & $2.18 \mathrm{E}+04$ & $7.81 \mathrm{E}-02$ & $2.72 \mathrm{E}+02$ & $1.66 \mathrm{E}+04$ & $1.85 \mathrm{E}+05$ & 0.92565 \\
\hline & & Average & $1.13 \mathrm{E}+05$ & $2.10 \mathrm{E}+03$ & $2.27 \mathrm{E}+02$ & $1.08 \mathrm{E}+05$ & $2.48 \mathrm{E}+05$ & 0.92979 \\
\hline & $4^{\text {th }}$ & $\mathrm{CR}$ & $2.02 \mathrm{E}+05$ & $1.04 \mathrm{E}+13$ & $2.64 \mathrm{E}+00$ & $1.96 \mathrm{E}+05$ & $1.98 \mathrm{E}+05$ & 0.96257 \\
\hline & & $\mathrm{HM}$ & $2.12 \mathrm{E}+04$ & $3.74 \mathrm{E}-02$ & $2.79 \mathrm{E}+02$ & $1.55 \mathrm{E}+04$ & $2.07 E+05$ & 0.95891 \\
\hline & & Average & $1.12 \mathrm{E}+05$ & $5.20 \mathrm{E}+12$ & $1.41 \mathrm{E}+02$ & $1.06 \mathrm{E}+05$ & $2.02 E+05$ & 0.96074 \\
\hline & $5^{\text {th }}$ & $\mathrm{CR}$ & $1.71 \mathrm{E}+05$ & $1.03 E+09$ & $8.03 E+01$ & $1.64 \mathrm{E}+05$ & $2.27 \mathrm{E}+05$ & 0.93871 \\
\hline & & $\mathrm{HM}$ & $1.82 \mathrm{E}+05$ & $1.13 E+10$ & $6.04 \mathrm{E}+01$ & $1.76 \mathrm{E}+05$ & $2.23 E+05$ & 0.93789 \\
\hline & & Average & $1.76 \mathrm{E}+05$ & $6.18 \mathrm{E}+09$ & $7.04 \mathrm{E}+01$ & $1.70 \mathrm{E}+05$ & $2.25 E+05$ & 0.9383 \\
\hline & $6^{\text {th }}$ & $\mathrm{CR}$ & $1.25 \mathrm{E}+05$ & $9.34 \mathrm{E}+03$ & $1.79 \mathrm{E}+02$ & $1.17 \mathrm{E}+05$ & $2.87 \mathrm{E}+05$ & 0.97453 \\
\hline & & $\mathrm{HM}$ & $1.44 \mathrm{E}+05$ & $2.76 \mathrm{E}+05$ & $1.50 \mathrm{E}+02$ & $1.36 \mathrm{E}+05$ & $2.79 \mathrm{E}+05$ & 0.9624 \\
\hline & & Average & $1.35 \mathrm{E}+05$ & $1.43 E+05$ & $1.64 \mathrm{E}+02$ & $1.27 \mathrm{E}+05$ & $2.83 E+05$ & 0.968465 \\
\hline
\end{tabular}

\subsection{Molecular structure}

The selected geometrical structure of the investigated ligand is calculated by optimizing their bond length and bond angles (Table 6). The highest occupied molecular orbital (HOMO) and lowest unoccupied molecular orbital (LUMO) energy gaps in Fig.6, $\Delta \mathrm{E}$, which is an important stability index, applied to develop theoretical models for explaining the structure and conformation in many molecular systems. The smaller is the value of $\Delta \mathrm{E}$, the more is the reactivity of the compound has the calculated quantum chemical parameters are given in (Table 7).

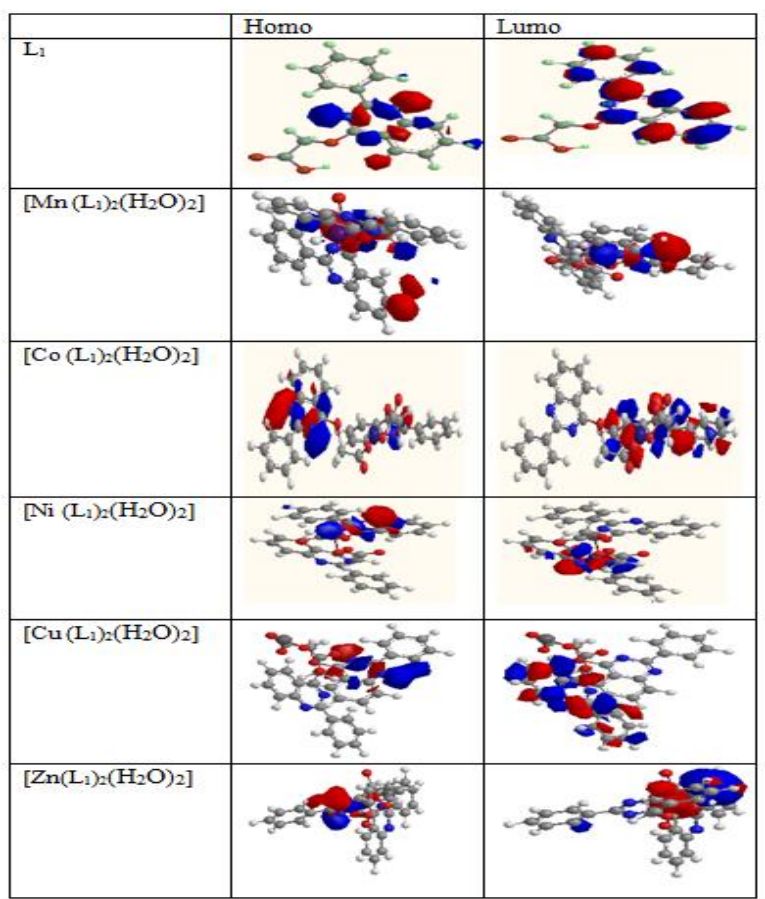

Fig. 6. The molecular structure of $\mathrm{L}_{1}$ and its complexes 
Synthesis and characterization of some metal complexes of 2-Phenyl-3,4-dihydro-quinazolin-4-yloxy..

Table 6: The calculated quantum chemical parameters for $\mathrm{L}_{1}$ and its complexes.

\begin{tabular}{|c|c|c|c|c|c|c|c|c|c|c|c|}
\hline Comp & $\begin{array}{c}\text { E }_{\text {HUMO }} \\
\mathrm{eV}\end{array}$ & $\begin{array}{c}\text { ELUMO }_{\text {LU }} \\
\mathrm{eV}\end{array}$ & $\begin{array}{l}\Delta \mathrm{E} \\
\mathrm{eV}\end{array}$ & $\begin{array}{c}\mathrm{X} \\
\mathrm{eV}\end{array}$ & $\begin{array}{c}\eta \\
\mathrm{eV}\end{array}$ & $\begin{array}{c}\delta \\
\mathrm{eV}\end{array}$ & $\begin{array}{l}\mathrm{Pi} \\
\mathrm{eV}\end{array}$ & $\begin{array}{c}\sigma \\
\mathrm{eV}\end{array}$ & $\begin{array}{c}\mathrm{S} \\
\mathrm{eV}\end{array}$ & $\begin{array}{c}\Omega \\
\mathrm{eV}\end{array}$ & $\begin{array}{l}\Delta \mathrm{N} \\
\max \end{array}$ \\
\hline $\mathrm{L}_{1}$ & $\begin{array}{l}-7.034 \\
\end{array}$ & -3.342 & 3.692 & 5.188 & 1.846 & 0.54171181 & -5.188 & 0.541711 & 0.923 & .290179 & 2.8104 \\
\hline$\left[\mathrm{Mn}\left(\mathrm{L}_{1}\right)_{2}\left(\mathrm{H}_{2} \mathrm{O}\right)_{2}\right]$ & 869 & -7.035 & 1.834 & 7.952 & 0.917 & 1.09051254 & -7.952 & 0.4585 & 0.4585 & 3.976 & 8.6717 \\
\hline$\left[\mathrm{Co}\left(\mathrm{L}_{1}\right)_{2}\left(\mathrm{H}_{2} \mathrm{O}\right)_{2}\right]$ & .032 & -3.345 & 3.687 & 5.1885 & 1.8435 & 0.54244643 & -5.1885 & 92175 & 0.92175 & 2.59425 & 2.8144 \\
\hline$\left[\mathrm{Ni}\left(\mathrm{L}_{1}\right)_{2}\left(\mathrm{H}_{2} \mathrm{O}\right)_{2}\right]$ & -7.089 & -7.042 & 0.047 & 7.0655 & 0.0235 & 42.5531915 & -7.0655 & 0.01175 & 0.01175 & 3.53275 & 300.65 \\
\hline$\left[\mathrm{Cu}\left(\mathrm{L}_{1}\right)_{2}\left(\mathrm{H}_{2} \mathrm{O}\right)_{2}\right]$ & -7.055 & -3.356 & 3.699 & 5.2055 & 1.8495 & 0.54068667 & -5.2055 & 0.92475 & 0.92475 & 2.60275 & 2.8145 \\
\hline$\left[\mathrm{Zn}\left(\mathrm{L}_{1}\right)_{2}\left(\mathrm{H}_{2} \mathrm{O}\right)_{2}\right]$ & -7.040 & -3.52 & 3.52 & 5.28 & 1.76 & 0.56818182 & -5.28 & 0.88 & 0.88 & 2.64 & 3 \\
\hline
\end{tabular}

Table 7: Bond length and Bond angels of ligand

\begin{tabular}{|c|c|c|c|}
\hline \multicolumn{2}{|c|}{ Bond length } & \multicolumn{2}{|c|}{ Bond angle } \\
\hline & & \multicolumn{2}{|l|}{1} \\
\hline $\mathrm{O}(21)-\mathrm{H}(33)$ & 0.971 & $\mathrm{H}(33)-\mathrm{O}(21)-\mathrm{C}(19)$ & 111.651 \\
\hline $\mathrm{C}(19)-\mathrm{O}(21)$ & 1.352 & $\mathrm{O}(21)-\mathrm{C}(19)-\mathrm{O}(20)$ & 124.710 \\
\hline $\mathrm{C}(19)-\mathrm{O}(20)$ & 1.212 & $\mathrm{O}(21)-\mathrm{C}(19)-\mathrm{C}(18)$ & 110.441 \\
\hline $\mathrm{C}(18)-\mathrm{H}(32)$ & 1.115 & $\mathrm{O}(20)-\mathrm{C}(19)-\mathrm{C}(18)$ & 124.844 \\
\hline $\mathrm{C}(18)-\mathrm{H}(31)$ & 1.114 & $\mathrm{H}(32)-\mathrm{C}(18)-\mathrm{H}(31)$ & 109.784 \\
\hline $\mathrm{C}(18)-\mathrm{C}(19)$ & 1.523 & $\mathrm{H}(32)-\mathrm{C}(18)-\mathrm{C}(19)$ & 107.640 \\
\hline $\mathrm{O}(17)-\mathrm{C}(18)$ & 1.413 & $\mathrm{H}(32)-\mathrm{C}(18)-\mathrm{O}(17)$ & 109.521 \\
\hline $\mathrm{C}(16)-\mathrm{H}(30)$ & 1.103 & $\mathrm{H}(31)-\mathrm{C}(18)-\mathrm{C}(19)$ & 109.850 \\
\hline $\mathrm{C}(15)-\mathrm{H}(29)$ & 1.103 & $\mathrm{H}(31)-\mathrm{C}(18)-\mathrm{O}(17)$ & 109.441 \\
\hline $\mathrm{C}(15)-\mathrm{C}(16)$ & 1.343 & $\mathrm{C}(19)-\mathrm{C}(18)-\mathrm{O}(17)$ & 110.582 \\
\hline $\mathrm{C}(14)-\mathrm{H}(28)$ & 1.103 & $\mathrm{C}(18)-\mathrm{O}(17)-\mathrm{C}(10)$ & 116.244 \\
\hline $\mathrm{C}(14)-\mathrm{C}(15)$ & 1.340 & $\mathrm{H}(30)-\mathrm{C}(16)-\mathrm{C}(15)$ & 115.907 \\
\hline $\mathrm{C}(13)-\mathrm{H}(27)$ & 1.103 & $\mathrm{H}(30)-\mathrm{C}(16)-\mathrm{C}(11)$ & 121.941 \\
\hline $\mathrm{C}(13)-\mathrm{C}(14)$ & 1.340 & $\mathrm{C}(15)-\mathrm{C}(16)-\mathrm{C}(11)$ & 122.152 \\
\hline $\mathrm{C}(12)-\mathrm{H}(26)$ & 1.103 & $\mathrm{H}(29)-\mathrm{C}(15)-\mathrm{C}(16)$ & 120.157 \\
\hline $\mathrm{C}(12)-\mathrm{C}(13)$ & 1.343 & $\mathrm{H}(29)-\mathrm{C}(15)-\mathrm{C}(14)$ & 119.593 \\
\hline $\mathrm{C}(11)-\mathrm{C}(16)$ & 1.351 & $\mathrm{C}(16)-\mathrm{C}(15)-\mathrm{C}(14)$ & 120.249 \\
\hline $\mathrm{C}(11)-\mathrm{C}(12)$ & 1.351 & $\mathrm{H}(28)-\mathrm{C}(14)-\mathrm{C}(15)$ & 120.536 \\
\hline $\mathrm{C}(10)-\mathrm{O}(17)$ & 1.372 & $\mathrm{H}(28)-\mathrm{C}(14)-\mathrm{C}(13)$ & 120.534 \\
\hline $\mathrm{N}(9)-\mathrm{C}(10)$ & 1.267 & $\mathrm{C}(15)-\mathrm{C}(14)-\mathrm{C}(13)$ & 118.930 \\
\hline $\mathrm{C}(8)-\mathrm{C}(11)$ & 1.357 & $\mathrm{H}(27)-\mathrm{C}(13)-\mathrm{C}(14)$ & 119.596 \\
\hline $\mathrm{C}(8)-\mathrm{N}(9)$ & 1.270 & $\mathrm{H}(27)-\mathrm{C}(13)-\mathrm{C}(12)$ & 120.155 \\
\hline $\mathrm{N}(7)-\mathrm{C}(8)$ & 1.270 & $\mathrm{C}(14)-\mathrm{C}(13)-\mathrm{C}(12)$ & 120.249 \\
\hline $\mathrm{C}(6)-\mathrm{H}(25)$ & 1.103 & $\mathrm{H}(26)-\mathrm{C}(12)-\mathrm{C}(13)$ & 115.871 \\
\hline $\mathrm{C}(10)-\mathrm{C}(5)$ & 1.345 & $\mathrm{H}(26)-\mathrm{C}(12)-\mathrm{C}(11)$ & 121.979 \\
\hline $\mathrm{C}(5)-\mathrm{C}(6)$ & 1.345 & $\mathrm{C}(13)-\mathrm{C}(12)-\mathrm{C}(11)$ & 122.150 \\
\hline $\mathrm{C}(4)-\mathrm{N}(7)$ & 1.265 & $\mathrm{C}(16)-\mathrm{C}(11)-\mathrm{C}(12)$ & 116.269 \\
\hline $\mathrm{C}(4)-\mathrm{C}(5)$ & 1.344 & $\mathrm{C}(16)-\mathrm{C}(11)-\mathrm{C}(8)$ & 121.868 \\
\hline $\mathrm{C}(3)-\mathrm{H}(24)$ & 1.104 & $\mathrm{C}(12)-\mathrm{C}(11)-\mathrm{C}(8)$ & 121.862 \\
\hline $\mathrm{C}(3)-\mathrm{C}(4)$ & 1.345 & $\mathrm{O}(17)-\mathrm{C}(10)-\mathrm{N}(9)$ & 117.756 \\
\hline $\mathrm{C}(2)-\mathrm{H}(23)$ & 1.103 & $\mathrm{O}(17)-\mathrm{C}(10)-\mathrm{C}(5)$ & 123.363 \\
\hline $\mathrm{C}(2)-\mathrm{C}(3)$ & 1.342 & $\mathrm{~N}(9)-\mathrm{C}(10)-\mathrm{C}(5)$ & 118.874 \\
\hline $\mathrm{C}(1)-\mathrm{H}(22)$ & 1.103 & $\mathrm{C}(10)-\mathrm{N}(9)-\mathrm{C}(8)$ & 122.488 \\
\hline $\mathrm{C}(6)-\mathrm{C}(1)$ & 1.342 & $\mathrm{C}(11)-\mathrm{C}(8)-\mathrm{N}(9)$ & 119.759 \\
\hline \multirow[t]{20}{*}{$\mathrm{C}(2)-\mathrm{C}(1)$} & 1.341 & $\mathrm{C}(11)-\mathrm{C}(8)-\mathrm{N}(7)$ & 119.960 \\
\hline & & $\mathrm{N}(9)-\mathrm{C}(8)-\mathrm{N}(7)$ & 120.280 \\
\hline & & $\mathrm{C}(8)-\mathrm{N}(7)-\mathrm{C}(4)$ & 121.303 \\
\hline & & $\mathrm{H}(25)-\mathrm{C}(6)-\mathrm{C}(5)$ & 121.452 \\
\hline & & $\mathrm{H}(25)-\mathrm{C}(6)-\mathrm{C}(1)$ & 118.281 \\
\hline & & $\mathrm{C}(5)-\mathrm{C}(6)-\mathrm{C}(1)$ & 120.267 \\
\hline & & $\mathrm{C}(10)-\mathrm{C}(5)-\mathrm{C}(6)$ & 123.350 \\
\hline & & $\mathrm{C}(10)-\mathrm{C}(5)-\mathrm{C}(4)$ & 116.937 \\
\hline & & $\mathrm{C}(6)-\mathrm{C}(5)-\mathrm{C}(4)$ & 119.714 \\
\hline & & $\mathrm{N}(7)-\mathrm{C}(4)-\mathrm{C}(5)$ & 120.117 \\
\hline & & $\mathrm{N}(7)-\mathrm{C}(4)-\mathrm{C}(3)$ & 120.040 \\
\hline & & $\mathrm{C}(5)-\mathrm{C}(4)-\mathrm{C}(3)$ & 119.843 \\
\hline & & $\mathrm{H}(24)-\mathrm{C}(3)-\mathrm{C}(4)$ & 120.475 \\
\hline & & $\mathrm{H}(24)-\mathrm{C}(3)-\mathrm{C}(2)$ & 119.194 \\
\hline & & $\mathrm{C}(4)-\mathrm{C}(3)-\mathrm{C}(2)$ & 120.332 \\
\hline & & $\mathrm{H}(23)-\mathrm{C}(2)-\mathrm{C}(3)$ & 120.121 \\
\hline & & $\mathrm{H}(23)-\mathrm{C}(2)-\mathrm{C}(1)$ & 120.058 \\
\hline & & $\mathrm{C}(3)-\mathrm{C}(2)-\mathrm{C}(1)$ & 119.822 \\
\hline & & $\mathrm{H}(22)-\mathrm{C}(1)-\mathrm{C}(6)$ & 120.084 \\
\hline & & $\mathrm{H}(22)-\mathrm{C}(1)-\mathrm{C}(2)$ & 119.894 \\
\hline
\end{tabular}


Synthesis and characterization of some metal complexes of 2-Phenyl-3,4-dihydro-quinazolin-4-yloxy..

\begin{tabular}{|c|c|c|c|}
\hline & & $\mathrm{C}(6)-\mathrm{C}(1)-\mathrm{C}(2)$ & 120.022 \\
\hline \multicolumn{4}{|c|}{$M n L_{1}$} \\
\hline $\mathrm{Mn}(41)-\mathrm{O}(43)$ & 1.813 & $\mathrm{Mn}(41)-\mathrm{O}(43)-\mathrm{C}(19)$ & 115.788 \\
\hline $\mathrm{Mn}(41)-\mathrm{O}(40)$ & 1.813 & $\mathrm{O}(43)-\mathrm{Mn}(41)-\mathrm{O}(40)$ & 91.640 \\
\hline & & $\mathrm{Mn}(41)-\mathrm{O}(40)-\mathrm{C}(38)$ & 116.193 \\
\hline \multicolumn{4}{|c|}{$\operatorname{CoL}_{1}$} \\
\hline $\mathrm{Co}(41)-\mathrm{O}(43)$ & 0.772 & $\mathrm{O}(43)-\mathrm{Co}(41)-\mathrm{O}(40)$ & 119.827 \\
\hline $\mathrm{Co}(41)-\mathrm{O}(40)$ & 0.768 & $\mathrm{Co}(41)-\mathrm{O}(40)-\mathrm{C}(38)$ & 120.131 \\
\hline \multicolumn{4}{|c|}{$\mathrm{Ni} \mathrm{L}_{1}$} \\
\hline $\mathrm{Ni}(41)-\mathrm{O}(43)$ & 1.790 & $\mathrm{Ni}(41)-\mathrm{O}(43)-\mathrm{C}(19)$ & 112.868 \\
\hline $\mathrm{Ni}(41)-\mathrm{O}(40)$ & 1.791 & $\mathrm{O}(43)-\mathrm{Ni}(41)-\mathrm{O}(40)$ & 91.892 \\
\hline & & $\mathrm{Ni}(41)-\mathrm{O}(40)-\mathrm{C}(38)$ & 108.604 \\
\hline \multicolumn{4}{|c|}{$\mathrm{Cu} \mathrm{L}_{1}$} \\
\hline \multirow[t]{3}{*}{$\mathrm{Cu}(41)-\mathrm{O}(40)$} & 1.811 & $\mathrm{Cu}(41)-\mathrm{O}(43)-\mathrm{C}(19)$ & 114.331 \\
\hline & & $\mathrm{O}(43)-\mathrm{Cu}(41)-\mathrm{O}(40)$ & 110.226 \\
\hline & & $\mathrm{Cu}(41)-\mathrm{O}(40)-\mathrm{C}(38)$ & 112.668 \\
\hline \multicolumn{4}{|c|}{$\overline{\mathrm{Zn} \mathrm{L}}$} \\
\hline $\mathrm{Zn}(41)-\mathrm{O}(43)$ & 1.891 & $\mathrm{Zn}(41)-\mathrm{O}(43)-\mathrm{C}(19)$ & 112.122 \\
\hline \multirow[t]{2}{*}{$\mathrm{Zn}(41)-\mathrm{O}(40)$} & 1.891 & $\mathrm{O}(43)-\mathrm{Zn}(41)-\mathrm{O}(40)$ & 119.660 \\
\hline & & $\mathrm{Zn}(41)-\mathrm{O}(40)-\mathrm{C}(38)$ & 112.052 \\
\hline
\end{tabular}

\subsection{Molecular docking}

Cancer can be described as the uncontrolled growth of abnormal cells. Breast cancer is one of the most recurring worldwide diagnosed and deadliest cancers next to lung cancer with a high number of mortality rates among females [17]. At global level, it accounted for more than 1.6 million new cases in 2010. The incidence or prevalence rate of the breast cancer in India is expected to be more than 90,000 in the coming years and over 50,000 women die each year.

Docking study showed the binding affinity, number of hydrogen bonds. It is interesting to note that the binding affinities have negative values. This reveals the high feasibility of this reaction. Molecular docking is a key tool in computer drug design $[18,19]$. The focus of molecular docking is to simulate the molecular recognition process. Molecular docking aims to achieve an optimized conformation for both the protein and drug with relative orientation between them such that the free energy of the overall system is minimized. The docked ligand were analysis breast Cancer $3 \mathrm{hb} 5$ as shown in Fig. 7.

The study simulates the actual docking process in which the ligand - protein pair-wise interaction energies are calculated using Docking Server [20] in (Table 8). According to our results, HB plot curve indicate that, compound binds to the two protein with hydrogen bond interactions of ligands (L1) with $3 \mathrm{hb} 5$ as shown in Fig 8. The calculated efficiency is favorable, Ki values estimated by Auto Dock were compared with experimental Ki values, when available, and the Gibbs free energy is negative. Also, based on this data, we can propose that interaction between, $3 \mathrm{hb} 5$ receptors and the ligands (L1) is possible. 2D plot curve of docking with ligands (L1) are shown in Fig 8. This interaction could activate apoptosis in cancer cells energy of interactions with ligand (L1). From the analysis of the values, it is evident that the binding energy of (L1) is higher value increased of binding affinity ligand towards the receptor. The characteristic feature of ligand represent in presence of several active sites available for hydrogen bonding. This feature gives them the ability to be good binding inhibitors to the protein and will help to produce augmented inhibitory compounds. The results confirm that, ligand is efficient inhibitor of $3 \mathrm{hb5}$-oxidorductase breast cancer.

Table.8: Energy values obtained in docking calculations of ligand $\left(\mathrm{L}_{1}\right)$ with receptor breast cancer $3 \mathrm{hb} 5$

\begin{tabular}{|l|l|l|l|l|c|c|}
\hline Comp & $\begin{array}{c}\text { Est. Free Energy } \\
\text { of Binding }\end{array}$ & $\begin{array}{c}\text { Est. Inhibition } \\
\text { Constant, Ki }\end{array}$ & $\begin{array}{c}\text { vdW + Hbond + desolv } \\
\text { Energy }\end{array}$ & $\begin{array}{c}\text { Electrostatic } \\
\text { Energy }\end{array}$ & $\begin{array}{c}\text { Total Intermolec. } \\
\text { Energy }\end{array}$ & $\begin{array}{l}\text { Interact. } \\
\text { Surface }\end{array}$ \\
\hline $\mathrm{L}_{\mathbf{1}}$ & $-6.91 \mathrm{kcal} / \mathrm{mol}$ & $8.64 \mathrm{uM}$ & $-7.98 \mathrm{kcal} / \mathrm{mol}$ & $-0.09 \mathrm{kcal} / \mathrm{mol}$ & $-8.08 \mathrm{kcal} / \mathrm{mol}$ & 717.445 \\
\hline
\end{tabular}

Fig. 7. The ligand $\left(\mathrm{L}_{1}\right)$ (green in (1A) and blue in (1B) in interaction with receptor breast cancer (3hb5)

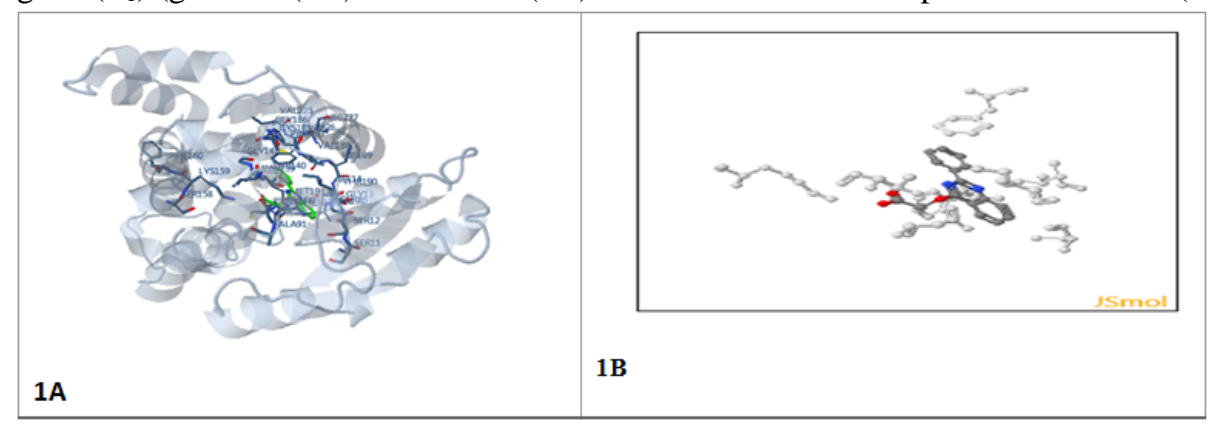


Fig. 8. 2D plot of interaction between the ligand $\left(\mathrm{L}_{1}\right)$ and receptor breast cancer $3 \mathrm{hb} 5$
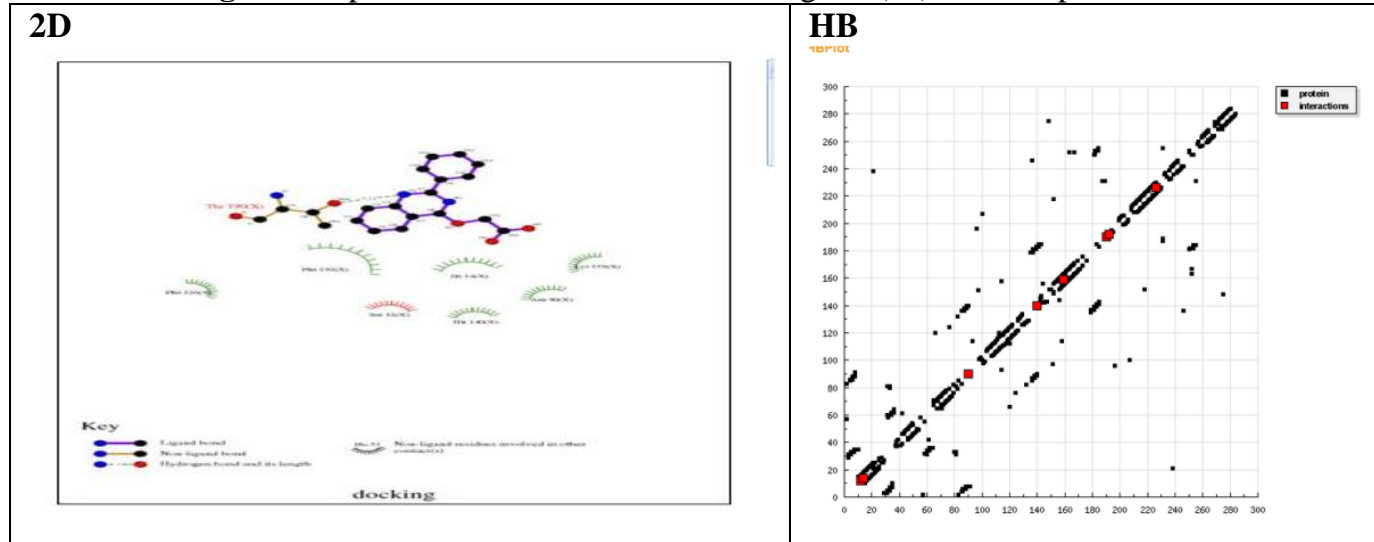

\subsection{Microbiological investigation}

The last part of this study investigate the antimicrobial activities of the synthesized compounds against Gram-positive bacteria Staphylococcus aureus, Gram-negative bacteria Escherichia coli and (Candida albicans). The antimicrobial activity was expressed by the inhibition zone. The results as shown in (table 8) showed that complexes exhibited good activity, whereas the $\mathrm{Cu}$ (II)and $\mathrm{Zn}$ (II) complexes are more active than the $\mathrm{Ni}$ (II), $\mathrm{Mn}$ (II) and Co(II) complexes against Gram-positive bacteria Staphylococcus aureus, Gram-negative bacteria Escher-ichia coli and (Candida albicans) greater than the standard drugs (Tetracycline, Novobiocin, Erythromycin and Neomycin).

Table.9: Antimicrobial analysis of ligand $\left(\mathrm{L}_{1}\right)$ and its complexes

\begin{tabular}{|c|c|c|c|}
\hline \multicolumn{3}{|c|}{ Antibacterial Activity } & \multirow{2}{*}{$\begin{array}{c}\text { Antifungal Activity } \\
\text { Zone Of Inhibition (mm) }\end{array}$} \\
\hline \multicolumn{3}{|c|}{ Zone Of Inhibition (mm) } & \\
\hline Code No. & Escherichia coli & Staphylococcus aureus & Candida albicans \\
\hline \multicolumn{4}{|c|}{ Samples (30 $\square$ I each) were analyzed using "disc diffusion method" } \\
\hline Control & -ve & -ve & -ve \\
\hline $\mathrm{MnL}_{1}$ & 0.8 & -ve & 0.9 \\
\hline $\mathrm{CoL}_{1}$ & 1.1 & 2.2 & 1.8 \\
\hline $\mathrm{NiL}_{1}$ & 1.3 & 2.0 & 2.3 \\
\hline $\mathrm{CuL}_{1}$ & 2.5 & 2.7 & 2.3 \\
\hline $\mathrm{ZnL}_{1}$ & 1.7 & 2.3 & 1.7 \\
\hline$\left(\mathrm{L}_{1}\right)$ & 1.7 & 2.0 & 1.8 \\
\hline Tetracycline & 0.7 & 0.6 & 1.2 \\
\hline Novobiocin & -ve & -ve & 2 \\
\hline \multicolumn{4}{|c|}{ Samples (15 $\square$ I each) were analyzed using "disc diffusion method" } \\
\hline Control & -ve & -ve & -ve \\
\hline $\mathrm{ZnL}_{1}$ & 1.5 & 1.7 & 1.7 \\
\hline $\mathrm{CuL}_{1}$ & 2.3 & 2.4 & 2.6 \\
\hline$\left(\mathrm{L}_{1}\right)$ & 1.7 & 1.4 & 1.1 \\
\hline Erythromycin & -ve & -ve & 2 \\
\hline \multicolumn{4}{|c|}{ Samples (10 $\square$ I each) were analyzed using "disc diffusion method" } \\
\hline Control & -ve & -ve & -ve \\
\hline $\mathrm{CuL}_{1}$ & 1.8 & 2.0 & 2.7 \\
\hline Neomycin & 1 & 1.2 & 1.1 \\
\hline
\end{tabular}

\section{Conclusion}

New Octahedral complexes of $\mathrm{Mn}(\mathrm{II}), \mathrm{Co}(\mathrm{II}), \mathrm{Ni}(\mathrm{II}), \mathrm{Cu}(\mathrm{II})$ and $\mathrm{Zn}(\mathrm{II})$ with (2-Phenyl-3,4-dihydroquinazolin-4-yloxy)-acetic acid $\left(\mathrm{L}_{1}\right)$ have synthesized and characterized using infrared, electronic and thermal. The ligand has been found to act as bidentate chelating agent. $\mathrm{L}_{1}$ complexes coordinate through the carboxyl group with 1:2 molar ratio as shown in Fig 9. Antibacterial screening of the complexes against Escherichia Coli, Staphylococcus aureus and antifungal (Candida albicans activities) was also investigated. The metal complexes were found to have varied degree of inhibitory effect against the bacteria and fungi greater than the standard drugs (Tetracycline, Novobiocin, Erythromycin and Neaomycin). 
$\mathrm{M}=\mathrm{Co}(\mathrm{II}), \mathrm{Ni}(\mathrm{II}), \mathrm{Mn}(\mathrm{II}), \mathrm{Cu}(\mathrm{II})$ and $\mathrm{Zn}(\mathrm{II})$

Fig.9. Proposed structure of the metal complexes

\section{References}

[1]. Hancock RD, Martell AE (1989). Ligand design for selective complexation of metal ions in aqueous solution. Chem. Rev. 9: 1875-1914.

[2]. Bhyrappa P, Young JK, Moore JS, Suslick KS (1996). DendrimerMetalloporphyrins: Synthesis and Catalysis. J. Am. Chem. Soc. 118:5708-5711.

[3]. Castillo-Blum SE, Barba-Behrens N (2000). Coordination chemistry of some biologically active ligands. Coord. Chem. Rev. 196: 3-30.

[4]. Mohan G, Rajesh N (1992). Synthesis and anti-inflammatory activity of N-pyridinobenzamide-2-carboxylic acid and its metal chelates. IndianJ. Pharm. 24: 207-211.

[5]. Kong D, Reibenspies J, Mao J, Clearfield A (2003). Novel 30-membered octaazamacrocyclic ligand: synthesis, characterization, thermodynamic stabilities and DNA cleavage activity of homodinuclear copper and nickel complexes. Inorg. Chim. Acta 342: 158-170.

[6]. V. Joshi, R. P. Chaudhari, Indian J Chem.26B, 602

[7]. VK. Srivastava, SS. Gulati, K. Shanker, Indian J Chem., 26B, 652 (1987).

[8]. DP. Gupta, S. Ahmad, A. Kumar, K. Shanker, Indian J Chem, 27B, 1060 (1988)

[9]. K. Sakai, H. Nahata, J. Jpn Kokai Tokyo Koho JP. 329, 6351 (1988).

[10]. V. Niementowski, J. Prakt Chem., 51, 564 (1895).

[11]. SN. Pandeya, D. Sriram, G. Nath, E D Clercq., J.Pharm. Acta Helvetiae. 74, 17 (1999).

[12]. E. J. De Beer, M. B. Sherwood, J. Bacteriol, 4, 459 (1945).

[13]. M.S. Refat, S.A. El-Korashy, M.A. Hussien, Canadian Chemical Transactions 2 (1), 97-107, 2014

[14]. M.S. Refat, S.A .El-Korashy, M.A. Hussien, Canadian Chemical Transactions 2 (1), 24-35, 2014

[15]. Coats, A.W.; Redfern, J.P. Kinetic Parameters from Thermogravimetric Data. Nature 1964, 201, 68- 69.

[16]. Horowitz, H.H.; Metzger, G. A new analysis of thermogravimetric traces. Anal. Chem. 1963, 35, 1464- 1468.

[17]. Bikadi, Z., Hazai, E. Application of the PM6 semi-empirical method to modeling proteins enhances docking accuracy of AutoDockJ. Cheminf. 1, 15 (2009)

[18]. T. A. Halgren Merck molecular force field. I. Basis, form, scope, parametrization, and performance of MMFF94 Journal of Computational Chemistry 17 (5-6), 490-519 (1998)

[19]. G. M. Morris, D. S. Goodsell, et al. Automated docking using a Lamarckian genetic algorithm and an empirical binding free energy function Journal of Computational Chemistry 19 (14), 1639-1662 (1998)

[20]. F. J. Solis and R. J. B. Wets Minimization by Random Search Techniques Mathematics of Operations Research 6 (1), 19-30 (1981) 